\title{
Fotografía, autobiografía y autoetnografía en Mitos: El Cuadrado del Tiempo
}

\begin{abstract}
Resumen
Este artículo tiene como objetivo presentar un ejercicio metodológico utilizando fotografía, autobiografía y autoetnografía, herramientas útiles en el marco de superación de procesos de vida traumáticos. Sontag y Barthes, entre otros autores, cuyos aportes a lo largo de la historia y evolución del arte fotográfico han sido fundamentales, ofrecen un marco hermenéutico-interpretativo: los conceptos studium/punctum propuestos por Barthes y el abordaje de la experiencia del hecho fotográfico de Sontag son asumidos por la autora durante el proceso. Los resultados que se presentan son una serie de narrativas auto etnográficas que se utilizaron como insumos en el proceso de creación de la obra Mitos: El Cuadrado del Tiempo.
\end{abstract}

\author{
Carmen Elena Viveros Celín \\ Maestría en Teoría y Práctica del \\ Documental Creativo \\ Docente Universidad del Norte \\ Barranquilla, Colombia \\ Correo electrónico: \\ ceviveros@uninorte.edu.co \\ ๑ orcid.org/0000-0003-4664-2650 \\ Google Scholar
}

Recibido: octubre 02 de 2018 Aprobado: abril 13 de 2020

\section{Palabras clave:}

autobiografía, autoetnografía, fotografía, investigación narrativa, foto-vOz. 


\section{Photography, autobiography and autoethnography in Myths: The Square of Time}

\begin{abstract}
This article aims to present a methodological exercise using photography, autobiography and autoethnography as useful tools in the framework of overcoming traumatic life processes. Sontag and Barthes, among other authors, whose contributions throughout the history and evolution of photographic art have been fundamental, offer a hermeneutical-interpretative framework: the studium/punctum concepts proposed by Barthes and the approach to the experience of the photographic fact of Sontag are assumed by the author during the process. The results presented are a series of auto-ethnographic narratives that were used as input in the process of creating the work Myths: The Square of Time.
\end{abstract}

Key words:

autobiography, autoethnography, photography, narrative research, photo-voice. 


\section{Introducción}

En el marco de mi proceso de investigación doctoral abordo la relación entre narrativa, memoria e imagen documental a través de cuatro casos de estudio de narrativas autorreferenciales de mujeres en Colombia relacionadas con el pasado traumático. En la narración de su memoria estas autoras recurren al uso de diversos materiales y procedimientos: objetos, fotografías, archivos audiovisuales e impresos, cartas, instalaciones museísticas, entre otros. En todos los casos, se produce la narrativa después de períodos dilatados (décadas) de silencio con respecto a la historia que cuentan, la cual atraviesa un proceso de duelo (por la pérdida de sus familiares) en el que recrean el pasado. En mi primer acercamiento a las posibles metodologías para abordar el estudio, identifiqué el frecuente uso de la narración autobiográfica por parte de estas mujeres, en cuya construcción está también implícita la autoetnografía para contar la vida de sus padres/abuelos (a la que se refieren), en relación con el contexto social que ellos vivieron, utilizan la narración autobiográfica no sólo para reelaborar la historia pasada sino también para narrarse a ellas mismas.

Por otro lado, desde el comienzo del proceso de investigación me había estado cuestionando acerca de mi interés en las experiencias de estas mujeres y sus narrativas personales. Debo confesar que, a veces, me he sentido culpable, como quien espía el dolor y la pérdida ajenos, sin haber experimentado una situación familiar de las dimensiones que ellas vivieron. Y, por lo tanto, sin la experiencia suficiente para adentrarme en el estudio y comprensión de sus narrativas en toda su complejidad.

Durante el proceso de la investigación, tuvo lugar una etapa de mi vida muy traumática para mí, devino en un estado emocional que se dilató a lo largo de varios años. Lo fui arrastrando silenciosamente, con vergüenza, ya que no podría de ninguna manera compararlo con lo que les sucedió a ellas 
(los sujetos de estudio de mi investigación), pero fue un suceso que me paralizó por momentos y me obligó a avanzar a marchas forzadas en los escenarios de mi vida. En medio del proceso personal, de superar mi propio duelo, durante la investigación, recurrí a la autobiografía y autoetnografía para indagar acerca de la naturaleza de mi propia pérdida y duelo a través de la fotografía. Esta metodología, de una manera orgánica, me conectó tanto con mi propia historia (pasado) y mis circunstancias vitales (presente), así como también con el mecanismo utilizado por los sujetos de mi estudio. Este hecho me permitió establecer un diálogo entre el pasado y el presente, de la misma manera como lo hacían mis sujetos de estudio, fortaleciendo así mí proceso investigativo, que hoy podría catalogar entre la investigación y la creación.

En este orden de ideas, este texto presenta un ejercicio metodológico en el que las fotografías se utilizan como materiales para elicitar la narración de mi propia memoria durante un proceso traumático y acercarme a la experiencia y a sus narraciones con más herramientas de comprensión.

\section{El método}

\section{La fotografía}

La fotografía se ha utilizado como una herramienta que ha permitido a muchos artistas lidiar con los traumas personales/familiares, trascendiendo hacia la esfera pública situaciones que solían inscribirse en el terreno de lo íntimo y privado. Es un movimiento que se inicia a partir de la década del setenta, cuando empiezan a hibridarse los géneros fotográficos. Colorado (2013) sostiene que: 
Con el posmodernismo las divisiones de géneros fotográficos en fotoperiodismo, foto-documentalismo o fotografía artística comenzaron a diluirse al punto de no poder distinguir claramente en algunos casos cuándo empezaba la obra de arte desde el punto de vista conceptual y dónde terminaba el aspecto registral. (párr. 2)

El mismo autor señala que otro factor fue la proliferación de la práctica del registro de situaciones íntimas de los fotógrafos, convirtiendo muchas veces la creación fotográfica en una cuestión vital, de supervivencia emocional: "para mostrar un aspecto del ser humano que no había sido develado antes por medio de la fotografía" (párr. 3).

Nan Goldin, por ejemplo, renovó la fotografía documental en la escena contracultural de Nueva York, entre las décadas del 70 y 80, haciendo públicas narrativas de la enfermedad, la violencia y el amor, fotografiando en la esfera de lo íntimo a familiares y amigos. Durante su propio proceso de desintoxicación para rehabilitarse de su adicción al consumo de drogas, Goldin realizó un documento autobiográfico de su proceso creativo. Pensaba que la creación a partir de lo conocido era la más honesta. Sus fotografías resultan de mirar la vida emocional en una escala reducida, como quien mira a través de un microscopio. Ella misma declaró que la cámara fue su salvación: "Sí, la fotografía salvó mi vida. Cada vez que paso por algo atemorizante, traumático, sobrevivo haciendo fotos" (Goldin, como se cita en Colorado, 2013, Sección Nan Goldin, párrafo. 3).

Es extensa la bibliografía que compila el trabajo de fotógrafos que construyen relatos autobiográficos a través de la fotografía. Jean Perret (2015, 2016, 2017) ha reseñado una gran cantidad de publicaciones sobre fotografía en el periódico suizo La couleur des jours, reflexionando sobre la obra de algunos de estos artistas. Acerca de Carpe Fucking Diem, libro que recoge el trabajo de la fotógrafa finlandesa Elina Brotherus, Perret (2016) comenta: 
Es un libro de tristeza, de estupor, de soledad, de espera. Y la experiencia de la vida que va, de la resiliencia, del duelo que sabe asumir los rasgos terriblemente paradójicos del renacimiento. Atmósfera del tiempo de enfermedad, de malestar general. (p. 35)

Sobre The Epilogue, que recoge la obra de la fotógrafa Laia April, Perret (2015) comenta, con relación a la historia que cuenta la serie fotográfica sobre Cammy Robinson, anclando en la palabra "amor":

"Amor". Esta palabra, este libro Epílogo es desbordante, traza la vida, hasta su muerte el 2 de septiembre de 2005 a los 26 años, de Cammy Robinson. Anoréxica, bulímica, en peligro de muerte desde su adolescencia, vivía en el entorno de una clase media adinerada establecida en Tennessee. Su terapeuta dice que este ambiente "estaba lleno de gente exitosa y hermosa con altas expectativas: la falta de atención y su predisposición a subir de peso la hacía muy vulnerable. (p. 38)

En otro texto, Perret (2017) condensa el universo emocional de Francesca Woodman plasmado en Devenir un ange de la siguiente manera:

una obra afirmada en apenas diez años, entre 13 y 22 años, exposiciones, un libro-catálogo para el inventario de una obra solitaria, con dimensiones existenciales desplegadas en cuerpo y alma. ¿Cómo hacerse un hueco en una vida ocupada por la urgencia de la afirmación del yo? (p. 36)

Y, finalmente, dos obras que se han convertido en referencia para mi propuesta de creación, de la artista Sophie Calle: Prenez soin de vous (2007) e Historias Reales (2016). En estas, elabora procesos muy personales de entendimiento de sus propias rupturas vitales en sendos trabajos de hibridación de materiales y formatos expositivos: texto escrito, fotografía y video instalación. Calle evidencia también la urgencia por reconstruir y transformar sus propias emociones a través de imágenes y textos, así como reinterpretaciones de estas apoyándose en la participación, en el caso de Prenez soin de vous, de otras personas. Muchos artistas han trabajado la fotografía desde una perspectiva autobiográfica. Unos para lidiar con sus traumas familiares, otros para cuestionar el devenir de la propia existencia, trabajar la aceptación del cuerpo, explorar la sexualidad, 
superar el maltrato físico, lidiar con deseos suicidas o adicciones, reflexionar sobre la muerte, etc.

\section{Investigación narrativa}

En el contexto de la investigación cualitativa se ha posicionado, durante los últimos veinte años, la corriente de los estudios narrativos que "han estado marcados por una aspiración general hacia la interdisciplinariedad y a un diálogo más intenso entre los enfoques literarios y los de ciencias sociales" (Meretoja, como se cita en Blanco, 2017, p. 69). Esta tendencia cuenta con varios focos de producción distribuidos mayoritariamente en las academias de Estados Unidos, Inglaterra, Canadá y América Latina, reseñados en un artículo publicado en la revista "Investigación Cualitativa", en el que Blanco (2017) sistematiza autores de diversas latitudes ${ }^{1}$. Recibe diferentes acepciones: narrative research, narrative inquiry, autoethnography; aunque las tres etiquetas acogen la creación de un universo narrativo único:

las narrativas (...) no son relatos dominados, como algunos críticos del trabajo narrativo han señalado, por clausuras, rigideces, evitaciones y ofuscaciones (...) Los relatos (...) narran singularidades, complejidades y multiplicidades, lo diferente, lo disidente y aquello difícil de entender. (Squire, como se cita en Blanco, 2017, p. 74)

Este tipo de investigación se adhiere a la autoetnografía como una perspectiva epistemológica que permite conocer el mundo de una manera diferente, tal como lo consideran autores pioneros y practicantes. Otra forma de abordar la experiencia humana. En el marco de esta investigación se toma como referencia directa el trabajo de Bochner y Ellis tal como se explica más adelante. La autoetnografía también cuenta con espacios académicos en Estados Unidos entre los que destacan: Centre for Narrative Research, The personal Narratives Group, International Congress of Qualitative Inquiry (desde 2005), 
Auto-ethnography, Personal Narrative, Reflexivity (de Ellis y Bochner) incluido en el Handbook of Qualitative Research (2005), Narrative Inquiry: Still a field in the Making (Chase, 2005), Handbook of Autoethnography (Holman, Adams \& Ellis, 2015). O en Inglaterra: Centre for Narrative Research en University of East London.

\section{Investigación basada en artes y photo voice}

En el contexto del presente texto, abordaré el caso que me ocupa desde una perspectiva autoetnográfica, apoyada por una variante personal de la técnica de photovoice. El actual término photovoice se refiere al método de investigación participativa basado en el uso de la fotografía, acompañada de narraciones de los autores que Caroline Wang y Mary Ann Burris (1994), habían Ilamado precisamente photo novella. Uno de sus proyectos con un grupo de mujeres, por ejemplo, incluía la tarea de "documentar, con cámaras, intangibles como 'preocupación' y 'amor'. Luego se dieron cuenta de que las fotografías solas no eran suficientes para entender los sentimientos de las mujeres. Las explicaciones - o narraciones de las fotografías - eran muy importantes" (Latz, 2017, p. 3), ya que las mismas remiten a la vivencia cotidiana. Este modelo, donde la herramienta de la fotografía es necesaria como dinámica, al incluir la voz de los participantes: "contrastaba con el modelo de investigación tradicional y convencional donde suelen ser tratados como sujetos pasivos" (Whyte, Greenwod \& Lazes, como se cita en Latz, 2017, p. 3).

Latz enmarca, además, esta metodología dentro de una corriente académica llamada investigación basada en artes, en este caso la fotografía, y cita una lista de diez principios en los que dicha corriente se basa. Cinco de ellos, que puedo resaltar como los más afines al enfoque de mi proyecto fotográfico "Mitos El cuadrado del Tiempo" y la narrativa autoetnográfica que a partir de él construyo, son: 
(...) 3. El propósito de la investigación basada en artes es plantear preguntas importantes y engendrar conversaciones en lugar de ofrecer significados finales. (...) 7. La investigación basada en las artes no es solo para educadores de arte o artistas profesionales. 9. El objetivo de la investigación basada en las artes no es reemplazar los métodos de investigación tradicionales; es diversificar la despensa de métodos que los investigadores pueden usar para abordar los problemas que les preocupan. 10. Utilizar las propiedades expresivas de un medio es una de las formas primarias en la que la investigación basada en artes contribuye al entendimiento humano. (Barone y Eisner, como se cita en Latz, 2017, p. 33)

\section{Autobiografía y autoetnografía}

Una estancia investigativa en L'École d'haute Études d'Art et de Design de Genève (Suiza) y mi asistencia por primera vez al 14th International Congress of Qualitative Inquiry en la Universidad de Illinois (Estados Unidos), durante el primer semestre de 2018, me sirvieron para realizar una reflexión profunda de cuáles enfoques y metodologías podrían iluminar mi trasegar investigativo, sin dejar de lado mi condición humana y mis circunstancias vitales en este período de mi vida que, no lo puedo negar, han afectado mi relación con el objeto y los sujetos de mi estudio. Considero que mis procesos intelectuales siempre van a estar mediados por mi propia subjetividad, aunque suene evidente, y - por lo tanto- no puedo obviarla. Gracias a estas reflexiones mi propia voz como investigadora se ha ido revelando y perfilando, al tiempo que he ido reconociendo que lo que me interesaba de mis sujetos de estudio era precisamente que sus narrativas estaban construidas desde ese lugar subjetivo que las hacía únicas circulando en clave autobiográfica. Esa experiencia única, personal, emocional, individual, subjetiva. No era casualidad, me di cuenta de que el objeto de estudio, los sujetos de estudio y el investigador estábamos alineados. Mis intuiciones iniciales encontraban un asidero epistemológico y metodológico desde donde abordar mi proceso de investigación respaldada por una tradición validada en los escenarios académicos en centros educativos y de investigación en otras partes del mundo. 
En el contexto de la investigación cualitativa, el enfoque autoetnográfico ha cobrado gran importancia, se trata de aquel en el que la experiencia de vida del investigador se convierte en una herramienta de mediación entre la experiencia individual y la colectiva, entre el mundo privado y el contexto social. Carolyn Ellis y Arthur Bochner podrían considerarse los pioneros de este enfoque investigativo, Ellis privilegia el autoconocimiento y sus propias emociones en sus procesos de investigación, entendiendo que "los investigadores autoetnográficos trabajan para conectar lo autobiográfico y personal con lo cultural y social privilegiando la acción concreta, la emoción, la encarnación, la autoconciencia y la introspección" (Ellis, como se cita en Douglas \& Carless, 2013, p. 85).

Así mismo, Bochner confiesa cómo su propia experiencia desafió las teorías y categorías de investigación cualitativa con las que él venía trabajando, aunque "había estudiado, teorizado y enseñado sobre la pérdida y el apego durante más de dos décadas (...) no empezó a conocer la pérdida hasta que [experimentó] la muerte de [su] padre" (Douglas \& Carless, 2013, p. 88).

En este orden de ideas, lo que pretendo con este ejercicio es construir una narrativa autoetnográfica a partir de mi propia experiencia personal para poder aproximarme — en el futuro — mejor a las narrativas construidas por mis sujetos de estudio: "en la investigación auto-etnográfica, el investigador es el centro epistemológico y ontológico alrededor del cual gira la investigación” (Spry, como se cita en Dubé, 2017, p. 7). En orden a encarar el estudio del mundo social a partir de mi perspectiva individual, ya que en este marco "La dialéctica yo-cultura es reinterpretada" (Denzin, como se cita en Dubé, 2017 , p. 7). En este caso, someto el material fotográfico a este diálogo para conectar lo personal con lo cultural, tal como lo plantean estos autores. 
Los autores especializados en autoetnografía afirman que esta se escribe usualmente en primera persona y que los textos pueden aparecer en múltiples formatos, apelando a una serie de nombres: "etnografía narrativa, etnografía personal, práctica creativa analítica, sociología lírica, autobiografía, narrativa heurística, etc." (Goodall, como se cita en Blanco, 2012, p. 172).

Por otro lado, la autobiografía constituye un género en el que las formas del yo se hacen presentes utilizando diversas formas de escritura. Ofrece la posibilidad de dar una dimensión histórica a la vida personal, formula preguntas individuales y colectivas en diversas temporalidades, además de permitir (re) interpretaciones de lo íntimo en el espacio público.

Russotto (2010) destaca la utilidad y versatilidad que ofrece esta forma de escritura, y sobre todo lo mucho que pueden ser aplicados en diversos ámbitos:

(...) en la exploración psicológica o para orientar la educación; son Ilaves secretas para sondear el submundo del hecho literario; consiguen dar pistas de la criminología; ayudan a recobrar la salud del amnésico; sirven para repensar el pasado de la historia social; establecen conexiones entre las estructuras de los imaginarios sociales y la obra artística (...) (p. 252)

Diferentes autores Camarero (2011), Loureiro (1991), Gusdorf (1991), entre otros, dan cuenta de esta modalidad de escritura a partir de la tridimensionalidad etimológica del concepto de auto-bio-grafía, siendo James Olney el precursor de esta descomposición:

a) autos, identidad, el yo consciente de él mismo y principio de una existencia autónoma; b) bios, continuidad vital de esa identidad, su despliegue histórico, el diálogo auto-bios es el diálogo de lo uno y de lo múltiple; y c) grafein, el medio técnico propio de las escrituras del yo, "la vida personal simplemente vivida, bios de un autos, beneficio obtenido de un nuevo nacimiento por mediación de la grafía". (Olney, como se cita en Camarero, 2011, p. 37) 
Por otro lado, desde la perspectiva de la investigación cualitativa, diversos autores definen la autoetnografía descomponiendo también etimológicamente la palabra:

proceso de investigación (grafía), cultura (ethnos) y self (auto). Los auto-etnógrafos (...) tienden a enfatizar sobre una u otra de estas tres dimensiones: sobre la dimensión del auto (el yo), sobre la dimensión del etnos (cultura) o sobre la dimensión gráfica. (Reed-Danahay, como se cita en Dubé, 2017, p. 7)

En este caso, al tratarse de un proceso tan personal, parto de las fotografías, como huellas nemónicas de vida, que me permiten construir las dimensiones del auto (yo) y grafía (proceso de investigación o de escritura). Se convierten además en material de estímulo para la creación de las narrativas. Para desarrollar la dimensión relacional (el etnos) con la cultura, utilizo autores cuyos aportes a lo largo de la historia y evolución de la fotografía han sido fundamentales. Barthes (1990) me ofrece dos conceptos claves para el proceso:

- Studium: "un campo que yo percibo bastante familiarmente, en función de mi saber, de mi cultura" (p. 63). Lo que me atrae y me hace interesarme por la fotografía y el diálogo que establezco con los rostros, gestos, decorados y acciones que contiene. Opera cada vez que me pongo en el lugar del espectador, yo me dirijo hacia lo contenido en ella.

- Punctum: opera en el sentido contrario, va de la fotografía hacia mí. Aquello que contiene la fotografía y me atraviesa emocionalmente: esos puntos sensibles, marcas, heridas. "Ese azar que en ella me despunta, pero que también me lastima, me punza" (p. 65).

Con Sontag (1981) abordo el "hecho fotográfico", que consiste en el análisis de la experiencia personal planteado en su ensayo "Sobre la fotografía", lo cual me ofrece lineamientos éticos para la reinterpretación de mis propias 
fotografías. Para esto, alterno mi lugar de análisis entre el studium y el punctum barthesiano. Otros autores guían también la reflexión: Joan Fontcuberta (2016) y Henri Cartier-Bresson (2014), conducen el componente narrativo de mi investigación hacia el ensayo personal y poético. Todo lo anterior me permite re-pensar y reflexionar sobre mis propias experiencias generando así las narrativas auto etnográficas, a partir de las fotografías, diálogo que articula el binomio yo-cultura más allá de mi propia historia (autobiografía).

Esta suerte de auto-bio-etno-grafía (autobiografía y autoetnografía), basada en el arte de la fotografía, realiza un viaje de ida y vuelta entre lo personal y lo social, en orden a comprender mejor el dolor que me había paralizado durante el proceso de investigación y me condujo nuevamente hacia la acción de la creación. La fotografía sirve para evocar, tal como lo declara Cartier-Bresson (2014):

algunas fotografías se asemejan a un relato de Chejov o de Maupassant. Son fugitivas y contienen todo un mundo. Pero uno no se da cuenta de eso en el momento de tomarlas. Es lo maravilloso de la cámara, eso surge de ti. (p. 44)

En este orden de ideas, presento un mapa conceptual (figura 1) que recoge los planteamientos anteriores y que se mueve también en tres direcciones que apuntalan la autobiografía (la historia personal) en las direcciones de la autoetnografía, utilizando las fotografías como elemento central que elicita las narraciones: 


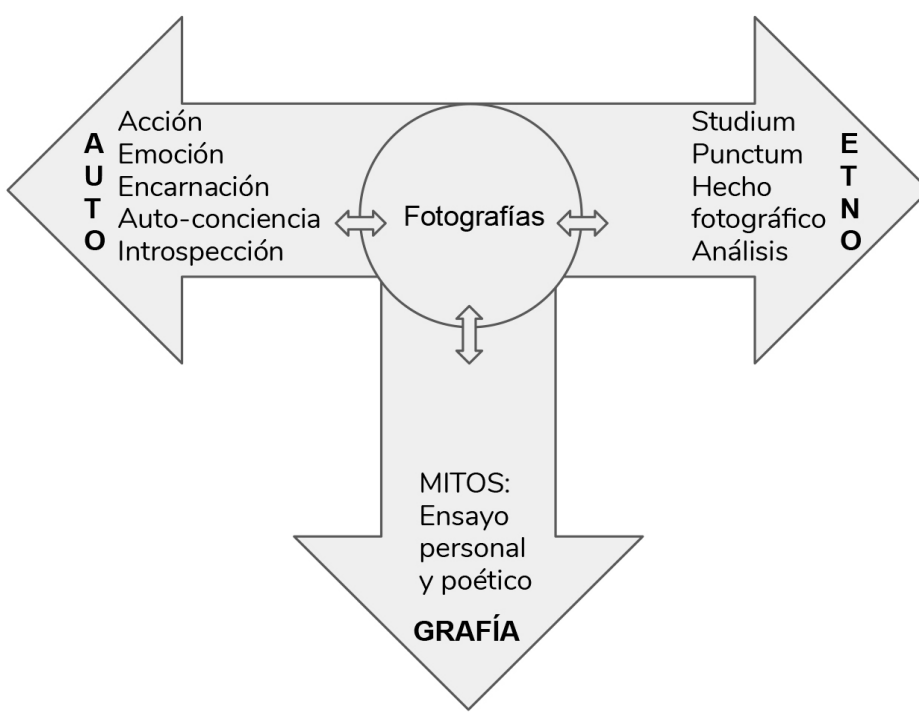

Figura 1. Mapa conceptual utilizado para el ejercicio metodológico. Fuente: elaboración propia a partir de Ellis (2015), Barthes (1990), Sontag (1981). Autora: Carmen Viveros

\section{Los datos: Mitos, El Cuadrado del Tiempo}

"Mitos: El cuadrado del tiempo" es una serie de diálogos entre pares fotográficas, pensado como un mecanismo ritual para volver a ellas y tratar de encontrar lo sagrado en lo arcano de mi alma. A pesar de todo, algo permanece en el misterio. Esa cualidad ha hecho que se conviertan, con el paso del tiempo, en momentos míticos de mi propia existencia. Cada vez que vuelvo sobre las fotografías que hago veo cosas nuevas y significados antes no imaginados, contienen misterios que a veces ni yo misma logro descifrar. 
La vida humana se ha organizado, a lo largo de la historia, a partir de mitos y rituales que los evocan. Convocan a los dioses, la naturaleza y al universo mismo en la participación de su origen y destino. Desde las civilizaciones más antiguas a las sociedades contemporáneas, atravesando infinidad de culturas y religiones, los rituales instalan un cierto orden del mundo dentro de un grupo que establece un diálogo temporal con aquel relato mítico que comparten. El término mito, tomado del griego Mú⿴os, era la palabra opuesta a logos, en el sentido de que ésta puede demostrar su validez y su verdad, mientras que mito se refiere a eventos "extrahumanos" que el ser humano reproduce a través de un rito o celebración para poder participar de lo divino (Muller, párr. 1).

Este proyecto fotográfico tiene su génesis en el álbum de fotos pa(i)sajes/(land) scapes que desde 2016 empecé a compartir en Facebook. Aunque público, se trataba de un proyecto fotográfico íntimo y silencioso que espigaba imágenes, "pasajes secretos" que me lanzaban hacia todas las direcciones posibles del tiempo, recuperando fotos antiguas y registrando nuevas, hasta llegar a considerarlo el lugar en donde — públicamente- construyo el relato mítico de mi propia existencia. En lo privado, todas esas imágenes me planteaban múltiples preguntas que me hacían enfrentarme a las contradicciones que esconden y que me ayudaban a calmar algún tipo de angustia en momentos en que la violencia exterior me agobiaba.

\section{¿Por qué "Mitos: El cuadrado del tiempo"?}

El proceso de creación de este proyecto fotográfico está motivado por el final de un ciclo de vida (mi matrimonio, 2012-2016, y posterior divorcio) que me sumió durante algunos años en un estado emocional muy complejo (doloroso) que decidí superar apoyándome en mi pasión por la fotografía, con tal de minimizar el impacto de esta circunstancia en mi desarrollo intelectual y laboral. Me di cuenta de que para poder comprender cómo otros lidian con 
la pérdida y el duelo (mis casos de estudio) debía también comprender cómo lidiaba yo con los míos. De manera paralela a la creación de Mitos, inicié sesiones de psicoanálisis. El resultado del proceso fue movilizarme hacia la acción de la creación artística transformando el dolor simbólicamente. Según Malinowski (1982) todo mito explica el origen o recreación de algo, conduce al individuo a la acción y le permite una representación simbólica de su experiencia.

El subtítulo, El cuadrado del tiempo, evoca la concepción original de la fotografía contenida en esa forma geométrica que, aunque estática, posee una cualidad temporal intrínseca. Con el tiempo, las fotografías, parecen haber cobrado vida y encontrado un orden orgánico.

\section{Del espacio físico al mítico a través de la fotografía: Pa(i)sajes / (Land)scapes}

Todo lo que no existe en la realidad física y material es, en cierta medida, una invención del ser humano. Susceptible de no ser cierto, puesto que habita únicamente el universo de las ideas (la imaginación) o de las emociones. Y ambas, al fin y al cabo, son inasibles. Sin embargo, dan cuenta de una dimensión de nuestra existencia, al tiempo que afectan nuestra vida cotidiana.

La pérdida de un ser querido algunas veces se pone en evidencia a través de rituales sociales o religiosos (Ej: el funeral) o de signos que son visibles sobre nuestro propio cuerpo: elegir un color para vestir es una manera de socializar el dolor. Otros signos, repliegan la existencia al silencio y al aislamiento sin posibilidad de exteriorizar nada, lo que me llevó a elaborar un proyecto de duelo personal, no a través del vestido, sino a través de la fotografía. Empecé creando un álbum en Facebook que recuperaba fotos antiguas de mis archivos privados y otros álbumes que ya existían en mi perfil de dicha red, al tiempo que registraba nuevas. A este nuevo álbum lo titulé 
"Pa(i)sajes/(Land)scapes". Pa(i)sajes, en español, suponía un juego de palabras, por un lado aludía a un cierto paisaje emocional que se impuso en mi ánimo a lo largo de varios años asociado al matrimonio y posterior divorcio, que muchas veces se materializaba en las fotos como un paisaje físico que transfigura lo que estaba sintiendo aunque aquello no era visible: "sea lo que sea lo que ella ofrezca a la vista, y sea cual sea la manera empleada una foto es siempre invisible: no es a ella a quien vemos" (Barthes, 1989, p. 68). Se trataba de una imagen que evocaba mis reflexiones y emociones, las cuales quedaban inscriptas en el orden de lo privado. También puede leerse como pasajes, un proceso de transición para poder pasar de un estado a otro, un pasaje de duelo. Me dedicaba a la reflexión a partir de mis emociones contenidas, en silencio e "invisibles", en las fotografías. La foto opera entonces como un lugar de encuentro entre el mundo físico y emocional. Así, el paisaje emocional se explicita gracias al proceso narrativo que tiene lugar posteriormente y que en Facebook, para mí, no era posible.

A partir de esta puesta en relación de dos fotografías, construyo narrativas autoetnográficas que se apoyan en mi autobiografía, sin saber a ciencia cierta lo que es real o ficticio, que ya poco se me hace necesario diferenciar. En su lugar ha cobrado importancia el hecho de la experiencia que vivo cada vez que me enfrento a las fotografías (hecho fotográfico) y lo que cada encuentro produce. Una experiencia nueva en cada encuentro, vivido como un ritual, pero también como un acto de creación. Como una persona religiosa que asiste a algún ritual dentro de su sistema de creencias y encuentra allí tranquilidad y sosiego. 


\section{Resultados y análisis: los diálogos fotográficos (photo voice) y las narrativas auto etnográficas}

En este apartado hago una presentación sistemática de los diálogos fotográficos y las narrativas autoetnográficas. Aunque el proyecto, en su dimensión creativa, plantea dos formatos de exhibición artística en espacios expositivos: exposición fotográfica y video instalación. Por lo tanto, los diálogos también están abiertos a la libre interpretación de otros espectadores. Cada diálogo ha sido titulado con un verbo (acción), seguido de la narrativa auto-bio-etno-gráfica y la presentación de las fotografías que la motivan.

\section{El punto de partida}

La fotografía de la izquierda, Memoria 1 (figura 2), fue tomada por mí en la puerta de una iglesia, en el preciso momento en que una pareja de recién casados ha salido y los invitados (entre ellos yo) les arrojamos pétalos de rosas rojas. El registro gráfico de la derecha, Triatlón (figura 3), me la envió un amigo apasionado por el triatlonismo que acumula evidencias de sus rutinas de entrenamiento, se trata de una imagen generada digitalmente por un teléfono celular al final de cada ritual de entrenamiento que él conserva como bitácora. En el proceso de este intercambio, me planteé esta posibilidad dialéctica entre mis propias fotografías. Mientras el registro de Triatlón supone una mirada impersonal, externa y distanciada, Memoria 1 me hacía pensar-sentir que mi ojo-cámara estaba justo en el centro de la acción y yo como fotógrafa no actuaba como un observador externo de mi propia experiencia como lo haría la imagen satelital. Por el contrario, se trataba de una fotografía que se generaba conmigo en el interior de la propia imagen (aunque yo no fuera visible) en una suerte de autobiografía emocional (la fotografía me habitaba y yo habitaba la fotografía), no en vano la fotografía fue realizada con una cierta urgencia de 
expresar un sentimiento de dolor que permanecía como un secreto dentro de mi propio ser al momento de su registro.

Mi mirada, si bien estaba mediada por la tecnología, lo estaba por sobre todas las cosas por una serie de memorias. El ritual frente a la cámara me remontaba al final de mi propio matrimonio (aunque la fotografía retrata el comienzo de otro) y en aquel momento yacían frente a mí sus ruinas, restos físicos siempre efímeros, pero la foto activaba un proceso desde lo colectivo del momento social hacia lo individual de mi memoria. El ejercicio me permitía elaborar una especie de metáfora del pasado.

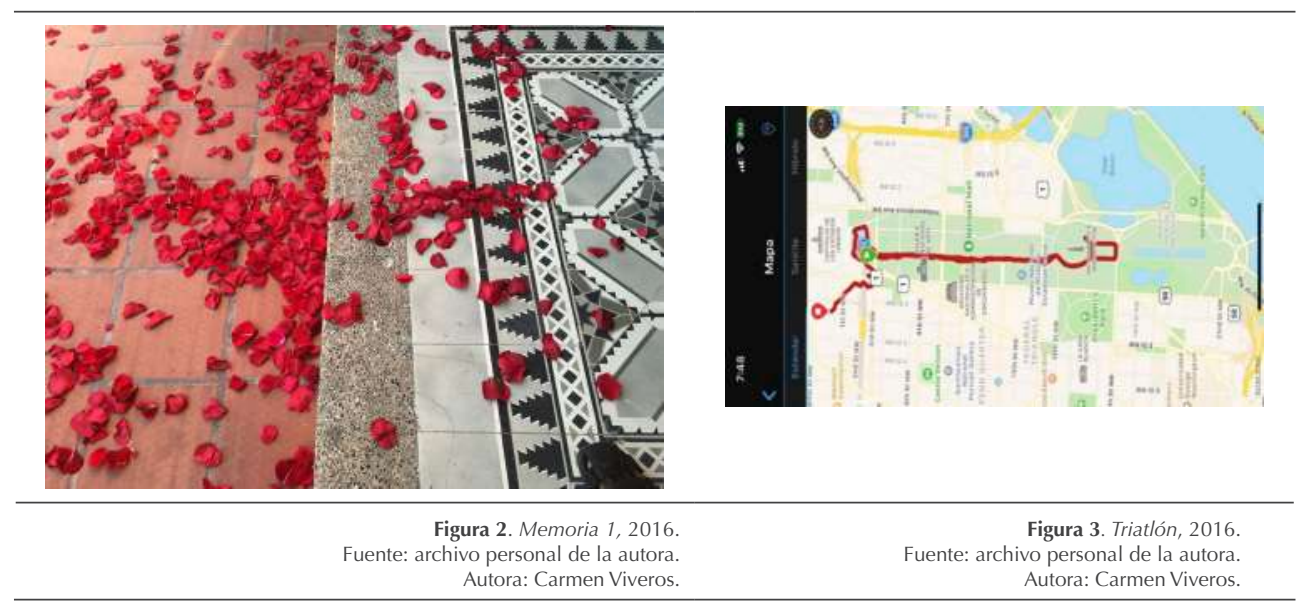

A partir de esta reflexión me di cuenta de que podía usar la fotografía, tanto para mi proceso personal como para avanzar en el estudio de metodologías de investigación que me ayudaran a no paralizarme y elevar el ancla del período doloroso que yo misma estaba viviendo. De la misma manera como lo habían experimentado los sujetos de mi estudio — por razones diferentes a las mías- 
décadas atrás, pero a los que aún siguen atados y evidencian en sus narrativas, como lo he estado yo a lo largo de estos últimos años. En los que mis propias fotografías fueron configurando una especie de archivo que guardaba el relato silencioso de mi propia historia que paulatinamente, a través de los años, fue ofreciéndome un espacio-tiempo para reflexionar sobre el pasado:

El relato autobiográfico ofrece un ámbito de sanación para un ego fracturado, pues exige reconocer el hilo rojo que hace de una historia de vida una historia integral digna de ser contada. El ejercicio autobiográfico sanador ofrece la oportunidad de ser uno mismo quien ordene su vida; en este nuestra propia voz se hace omnisciente y elige el rumbo. Gracias al relato autobiográfico, quien se narra puede darle un sesgo de autor a su propia historia y redefinir tanto sus relaciones como su papel en las historias de otros". (Leal Acosta y Ruiz Soto, 2010, p. 91)

Hoy el principal pilar de la imagen es su compartibilidad (Gunthert, como se cita en Fontcuberta, 2016, p.120). Y este diálogo natural, a través del WhatsApp, es producto de esa nueva dimensión comunicacional de la imagen que ha sido posible gracias al profundo cambio que ha producido la tecnología digital y móvil, que pone en evidencia esta nueva posibilidad dialéctica de la fotografía: "la industria de la telefonía marca el rumbo de la fotografía, lo primordial ya no es imprimir la imagen, sino enviarla integrándola en un proceso conversacional" (Fontcuberta, 2016, p. 114).

\section{(Des)ordenar}

En consecuencia, me propuse encontrar entonces una nueva imagen que dialogara con Memoria 1 (figura 2), mi propio orden de las cosas, de mi vida, capaz de resignificar esta vuelta al pasado, re creando el origen de este proyecto, para que naciera el mito, producto de mi propia invención, que es en últimas el objetivo de todo trabajo de memoria ejemplar, que supusiera un mecanismo para comprender lo que pasó, desde el presente, y ofreciera posibilidades para pensar el futuro, entendiendo la memoria ejemplar como 
"una memoria que recupere el pasado en aras de mejorar el presente y pensar el futuro" (Todorov, como se cita en Quílez, 2010, p. 27). Fue entonces cuando el diálogo (des)ordenar tuvo lugar. La fotografía Memoria 2 (figura 4) recompone los elementos físicos y también emocionales, presentes en Memoria 1, borra las huellas dejadas por el ritual del matrimonio (los pétalos de rosas) sin renunciar a la misma instancia de enunciación, seguir siendo yo la que mira y crea esta nueva representación de mi mundo interior detrás de la cámara, proyectada hacia un tiempo futuro.

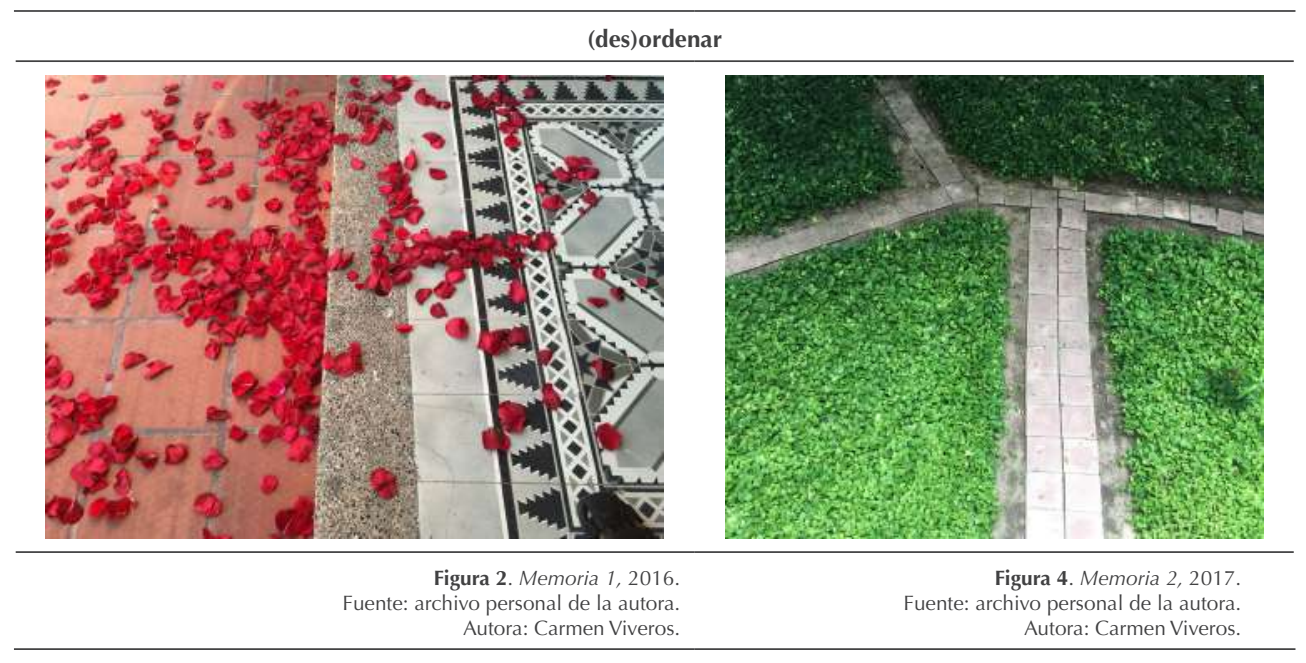

Con Memoria 2 (figura 4) me propuse el registro de una fotografía que embelleciera el pasado, caótico y desordenado en mi mente y en mi corazón. En la que desaparecieran, simbólicamente, las huellas del dolor. Losilla (2008) afirma que: 
Las diferentes formas de la representación del dolor, la enfermedad y la muerte en la autobiografía (...) provienen de un solo deseo: embellecer la desgracia de la degradación y el desmoronamiento, de manera que esa mascarada provoque a su vez la ilusión de estar hablando en primera persona de aquello que me está matando, cuando en realidad lo transfiguro para mover a la compasión, o utilizarlo a modo de exorcismo, que a su vez es otra forma de embellecimiento. (p. 122)

En Memoria 2 un camino de piedra de dos filas unidas de baldosas se divide en dos nuevos caminos en direcciones opuestas. La última baldosa del camino de la derecha está fracturada, pero el camino vuelve a empezar, se regenera, como la naturaleza en torno a ella. Los nuevos caminos se pierden en el borde de la imagen, continúan más allá de los límites de esta. La continuidad no se divisa, pero esa misma invisibilidad hace posible abrir el espacio para la imaginación. Lo que está fuera de cuadro es tan importante como la imagen misma. El tiempo, el lugar, la memoria, el silencio y la poesía son piezas fundamentales para entender el discurso.

\section{(Re)nacer}

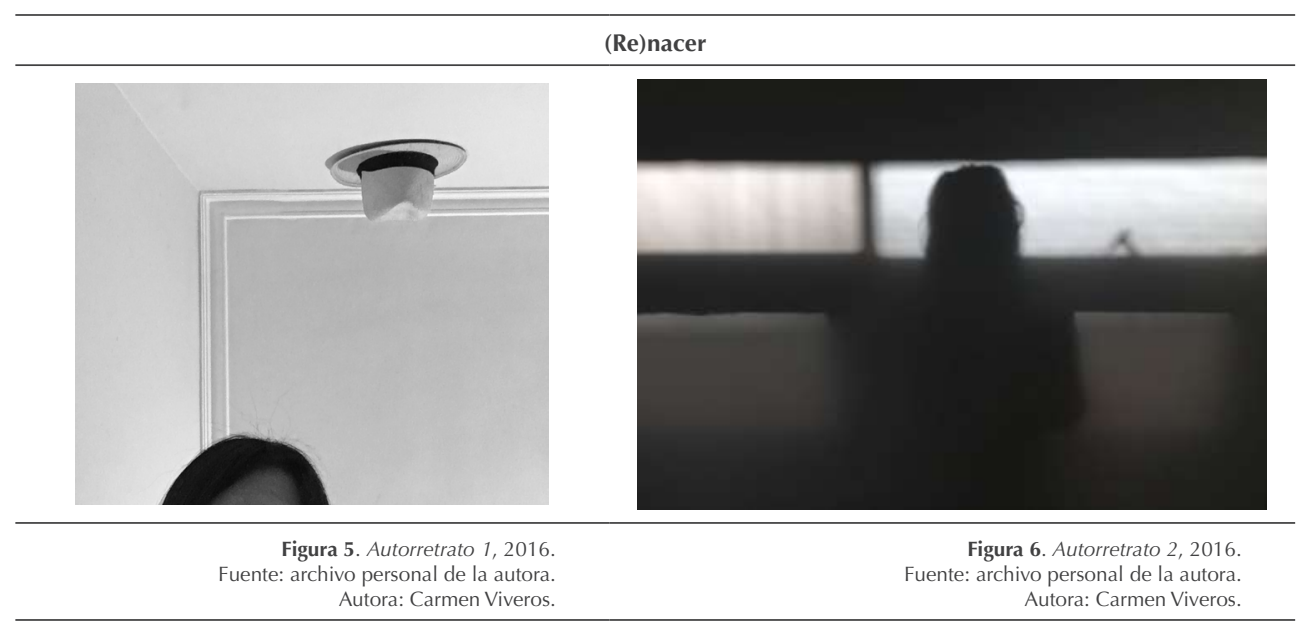


En los primeros días, después del divorcio, el espacio seguía siendo el mismo, aquel espacio íntimo compartido. En Autorretrato 1 (figura 5) un objeto me atrae hacia la fotografía, representa la presencia de la ausencia. Tardé dos años en deshacerme de él. La fotografía ha prolongado su permanencia en mi memoria y con ella he podido observar cómo mis emociones han mutado a través de los años, aunque el objeto permanezca en ella inmutable. Yo también experimenté una especie de pseudo-presencia. En Autorretrato 2 (figura 6), sobre la pared del lobby que da acceso al apartamento donde habíamos vivido y compartido, mi sombra se proyectó como un espectro. Durante estos años coincido con varias colegas que atraviesan por el mismo proceso, asisto a la confesión de sus sentimientos y sus dificultades para continuar. Todas guardamos silencio. Creo que la mayoría de las mujeres nunca hablamos sincera y públicamente acerca de este sentimiento de pérdida cercano a la muerte. Es precisamente el ritual de la muerte el que nos hace más conscientes de la naturaleza de la vida y, por lo tanto, a "(...) la presencia del yo, del sujeto, del alma sensible sometida a la prueba de la fotografía. Al tiempo interrumpido, a la plasmación de lo que fue" (Barthes, 1990, p. 22). En las fotografías, yo estoy también ausente del lugar, eso que estoy sintiendo (Ilamémosle tristeza, rechazo, vergüenza) me impiden verme como una presencia real. Estoy fracturada e incompleta, me siento sin identidad, cuestionándome ¿quién soy yo?, como una sombra. Solo deseo que la vida termine. Esta fotografía posee el punctum, término propuesto por Barthes, el dolor. En aquel momento, haciendo la fotografía, moría, pero con el paso del tiempo, al colocarme en el lugar del espectador me doy cuenta de que el proceso de divorcio era una oportunidad para seguir estando viva. He tenido que volver muchas veces a este diálogo para comprenderlo. "Lo que la fotografía reproduce al infinito únicamente ha tenido lugar una sola vez: la fotografía repite mecánicamente lo que nunca más podrá repetirse existencialmente" (Barthes, 1990, p. 31): el dolor es efímero. 
El titular en inglés, (Land)scapes, del álbum de Facebook también aludía a otro sentimiento presente en aquella travesía vital, las fotografías funcionaban como una caja de resonancia de una(s) cierta(s) ausencia(s), así como mi tendencia a escapar (scape) de la esfera pública, del paisaje físico, a los que me ha costado regresar después del divorcio, atravesada por un deseo constante de "morir", como quien quiere escapar de la tierra (espacio físico) y de la vida misma. Esto coincide con noticias que me llegan del incremento del índice de suicidios en algunas instituciones educativas. Reflexiono cómo puede ayudar la fotografía a este proceso de manera particular, y más ampliamente en el ámbito educativo, indagar la imagen a partir de lo que se ve, pero también de lo que no se ve. Para Sontag (1981) "una fotografía es a la vez una pseudopresencia y un signo de ausencia" (p. 33). Comencé a realizar lecturas acerca del suicidio para tratar de entender este sentimiento intelectualmente. El mito de Sísifo de Albert Camus Ilegó a mí en este período. Todo intentando entender filosóficamente el sentido de la vida y por lo tanto ese deseo extraño de querer morir, de no encontrarle sentido a la vida.

Para combatir el sentimiento de "querer morir", no seguir viviendo, que se apoderó de mí a partir del final de mi matrimonio, produje el diálogo (re)nacer. Suponía la posibilidad de morir, pero también la de nacer al mismo tiempo. "Todas las fotografías son memento morí. Hacer una fotografía es participar de la mortalidad, vulnerabilidad, mutabilidad de otra persona o cosa" (Sontag, 1981, p. 32).

\section{Purificar}

Vuelvo al pasado. En 2007 y 2008 realicé dos viajes a Estambul, este diálogo recoge dos de las fotografías registradas en ese período que recupero casi diez años después. Me llamaba la atención la marcada presencia de los hombres en el espacio público, por sobre la presencia de las mujeres. Sin embargo, conservo una fotografía que logré hacer de una mujer que esperaba en la acera. 
La llamé "La espera" (figura 7). En esta fotografía tuve que aplicar un profundo zoom in para poder dejar fuera a todos los transeúntes que paseaban por la acera. Quería dejar a la mujer de la foto siendo la protagonista. Ella estaba sola sentada en un banco rodeada de algunas bolsas negras, simplemente esperando.

Esta fotografía dio origen a este diálogo, purificar, hay una urgencia por reivindicar la presencia de la mujer en el espacio público, en dos momentos que supongo de una profunda soledad de los sujetos en el espacio público, pero al mismo tiempo de una paz extraña.

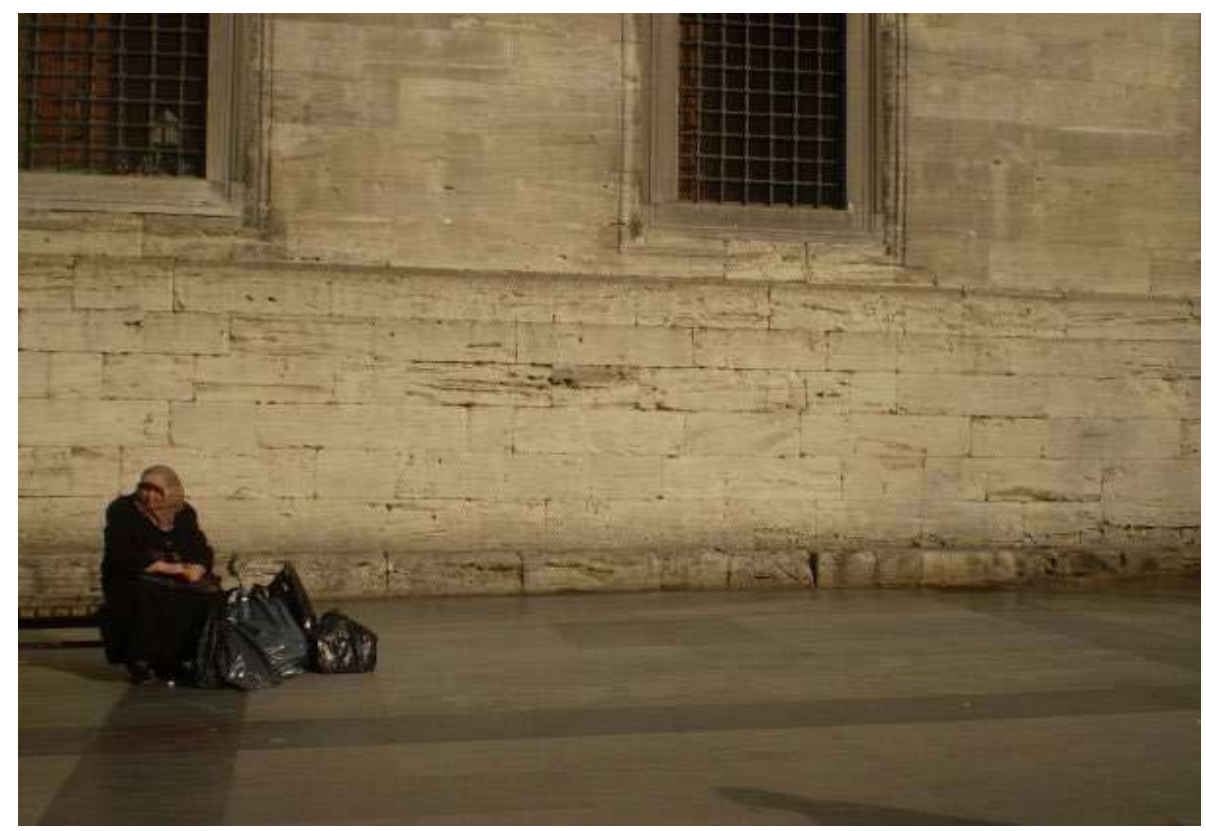




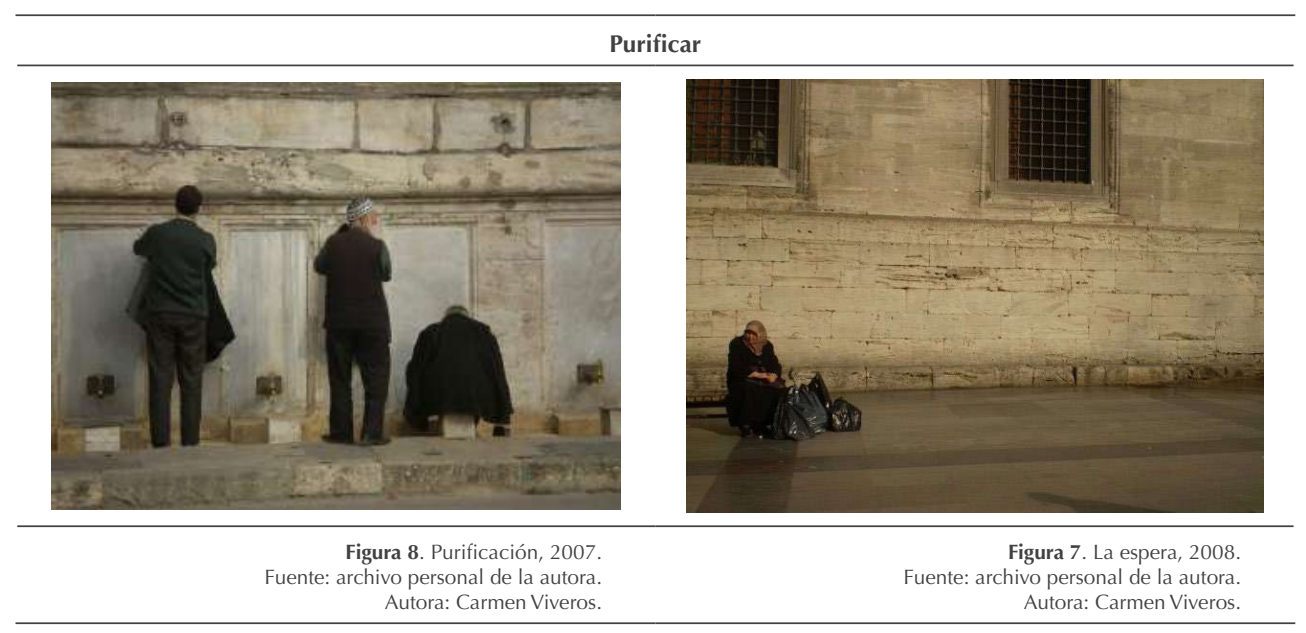

En Purificación tres hombres lavan sus manos y pies antes de ingresar en una mezquita (figura 8). Imaginé un nuevo diálogo en el que ella y ellos se miran mutuamente de una fotografía a otra. Al mismo tiempo, este diálogo me sugería reconciliarme con la figura masculina a través de la mirada, como dialogaba con mi pasado a través de las fotografías, una forma simbólica de purificación de ambas partes. Ellos (ella y él) en un país (Turquía) supremamente machista. Puedo recordar el Ilamado a la oración a diferentes horas del día, un sistema especial de megafonía amplifica el sonido místico de al-adam (el Ilamado a la oración) que resuena en toda la ciudad, rituales en los que ellos, a pesar de todo, comulgan juntos bajo un mismo sistema de creencias. La mirada íntima se desborda en el espacio público de gestos y rituales que actualizo diez años después. 


\section{Revelar}

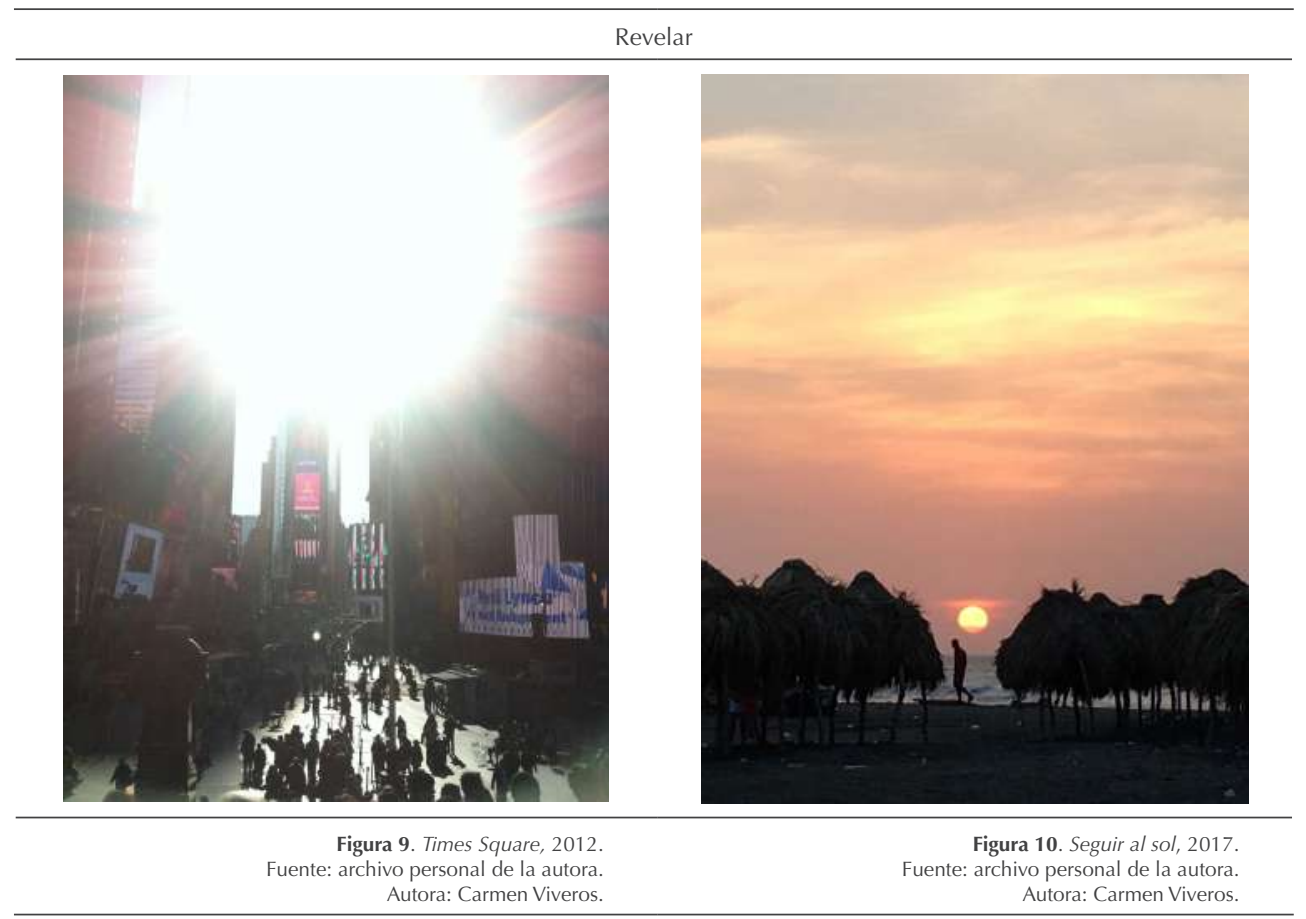

La fotografía en Times Square (figura 9), registrada — adrede_ a contraluz, expone este centro neurálgico del mundo de los negocios y el turismo en Nueva York, en donde el movimiento y casi todo se multiplica de manera exacerbada, las personas, los automóviles, los negocios, el dinero. "Las fotografías pueden ser más memorables que las imágenes móviles, pues son fracciones de tiempo nítidas" (Sontag, 1981, p. 35). En mi fotografía el movimiento se detiene, el espacio se oscurece - paradójicamente- gracias al exceso de luz que entra en la lente 
de la cámara. Como las imágenes en la era de la "postfotografía", tal como se plantea en Fontcuberta (2016): "La postfotografía deviene así un contexto de pensamiento visual que rubrica la desmaterialización de la imagen y de su autoría, y que disuelve las nociones de originalidad y de propiedad, de verdad y de memoria". Viví durante doce años en Barcelona, en 2012 volví a vivir en Barranquilla, mi ciudad de origen ubicada en el Caribe colombiano (figura 10), cuyo sol canicular también opaca la visión de las contradicciones propias de las ciudades latinoamericanas, no tan alejadas del consumo excesivo planteado por el capitalismo y las desigualdades que éste engendra. Una/otra caverna.

Estas imágenes representan aquella caverna que evoca Sontag en relación con la fotografía, en donde los seres humanos quedamos reducidos a nuestras sombras, las platónicas. No pretendía hacer apología ni del consumo ni del turismo voraz que tiene lugar en este gran centro del capitalismo, en su lugar quería construir una mirada crítica sobre el mismo. "La humanidad persiste irremediablemente en la caverna platónica, aún deleitada, por costumbre ancestral, con meras imágenes de la verdad" (Sontag, 1981, p. 15). Registro ambas fotografías separadas cinco años una de otra. El mundo es considerado una caverna, en estas imágenes intento explorar un código visual en donde nada es visible, todo es opaco (incluso oscuro), pero en cambio es esta misma "oscuridad" la que dota a las imágenes de la posibilidad ética que tienen de ser miradas, para Sontag (1981):

Esta misma avidez de la mirada fotográfica cambia las condiciones del confinamiento en la caverna, nuestro mundo. Al enseñarnos un nuevo código visual, las fotografías alteran y amplían nuestras nociones de lo que merece la pena mirar y de lo que tenemos derecho a observar. Son una gramática y, sobre todo, una ética de la visión. (p. 15)

El divorcio me hizo pensar en un matrimonio fallido. El fracaso de un proyecto personal. Una caverna temporal. Nada podía verse tal cual es, solo sombras. En las fotografías, todas tomadas con un teléfono celular, construyo una especie de "error", de "fallo fotográfico" adrede: exceso de luz, sobreexposición, de 
alguna manera ellas se convierten en metáforas (símbolos) del "fracaso" que me permiten desentrañar reflexiones en esa misma ciudad (New York) en donde tuvo lugar mi "luna de miel". Volver al pasado para transformarlo.

\section{Confesar}

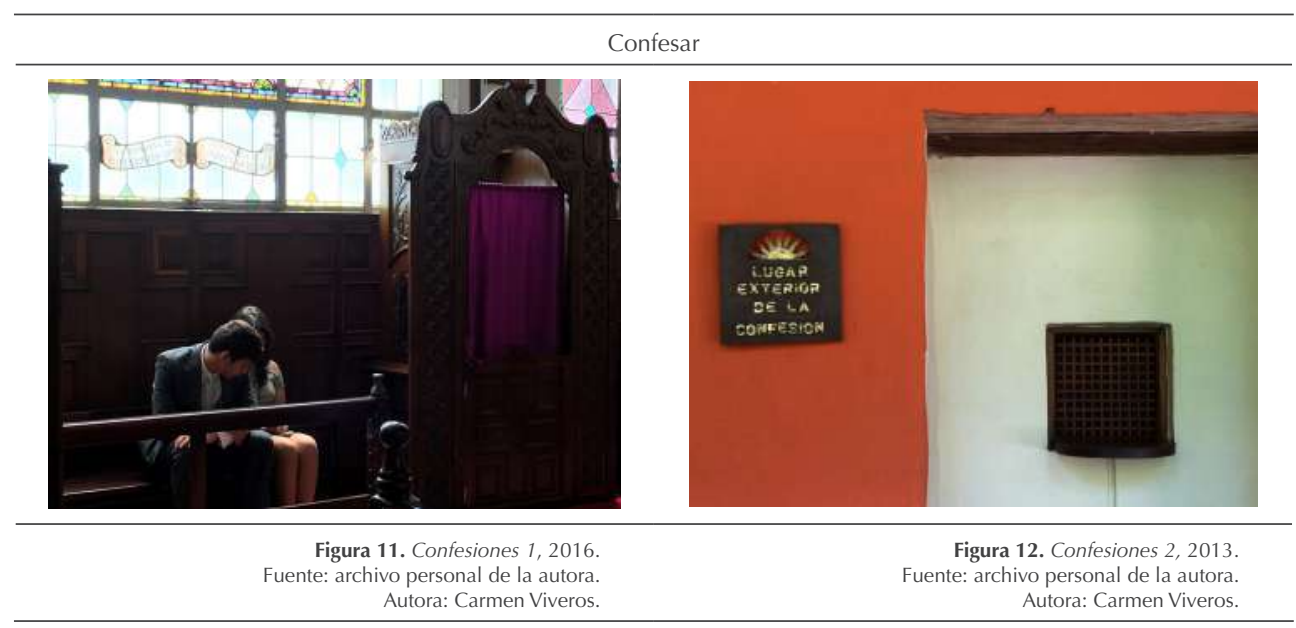

"Todos los usos talismánicos de las fotografías expresan una actitud sentimental e implícitamente mágica: son tentativas de alcanzar o apropiarse de otra realidad" (Sontag, 1981, p. 33). Confesiones 1 se convirtió en una especie de fotografíatalismán a través de la cual, en un diálogo con el pasado, el dolor trasciende de lo privado a lo público, de lo real a lo ficticio. Es el mes de mayo de 2016. Mi sobrina Valeria participa de su primera comunión en una iglesia de la ciudad. Son los primeros días después de mi divorcio. Asisto sola a la ceremonia, mi corazón está deshecho. Me ubico al final de la iglesia, que está abarrotada, estoy rodeada de decenas de personas y sin embargo me siento sola. Encuadro a la pareja que aparece en la foto junto al confesionario (figura 11, Confesiones 1). Confesiones 2 
(figura 12) registra la estructura exterior que se conserva en el Claustro de Santa Clara (una reliquia de la colonia en la ciudad de Cartagena) que visité en 2013 junto con el que era mi esposo y su familia, dialoga con la primera fotografía en tanto la leyenda inscrita en la placa de madera junto a la rejilla confesional ("lugar exterior de la confesión") evoca un doble juego con el pasado. Uno de los recuerdos que tengo de mi infancia es precisamente el de esperar mi turno para confesarme: estoy en una fila en la capilla del colegio católico donde estudié durante once años, muerta de miedo, pensando en "mis culpas" (tengo 10 años), me aterra y avergüenza contarle "mis pecados" al cura que cobardemente se esconde detrás de una rejilla y una cortina siempre oscura, convirtiendo aquel ritual religioso en un proceso que me llena de temor pero al que debo someterme socialmente. Este es el lugar exterior de mi confesión. Vuelvo a estar en la parte exterior del confesionario, ya no siento miedo. Confesar el miedo y el dolor públicamente me han ayudado a dialogar con ellos y sanarlos.

\section{(Re)producir}

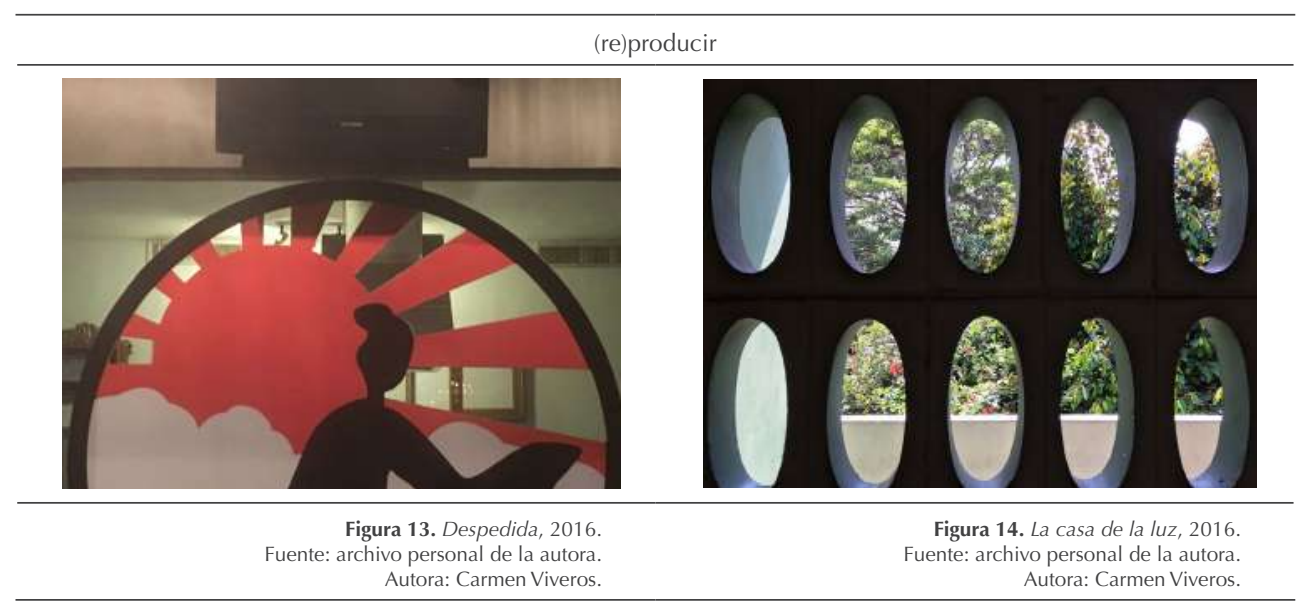


"Me cansé de ver al sol ponerse por el oeste y decidí seguirlo", recita un personaje del cineasta Bud Boetticher, hay un lugar en Barranquilla con la ilustración de la fotografía Despedida (figura 13), es un restaurante donde solía ir frecuentemente durante el matrimonio. La ilustración está dispuesta en uno de los cristales que sirve como división entre un espacio y otro. El espacio privado y el público. Es una mujer que se funde con el sol, la fuente de luz por excelencia. Visito a mi amiga G. M. en su casa siempre luminosa, La casa de la luz (figura 14), aunque sea de noche. Me gusta llamarle La casa de la luz. Los calados de su balcón permiten ver la luz del exterior. En ambas fotografías las visiones a través de y gracias a la luz se diversifican y se multiplican. Las formas de la luz son, en ese momento, las visiones de un "futuro incierto" pero luminoso. Y lo único que deseo es que ellas se reproduzcan infinitamente a través de mis fotografías.

La totalidad de lo expuesto hasta este punto se escribió en 2018 (dos años después del divorcio). Me encontraba en pleno proceso personal e investigativo. A finales de ese mismo año se expuso Mitos: El Cuadrado del Tiempo en el marco de un taller que impartí a un grupo de mujeres sobre documental y autobiografía (Figuras 15 y 16), dividido en una parte conceptual teórica y la presentación de la experiencia del ejercicio de investigación-creación que presento en este artículo utilizando el enfoque autoetnográfico. 


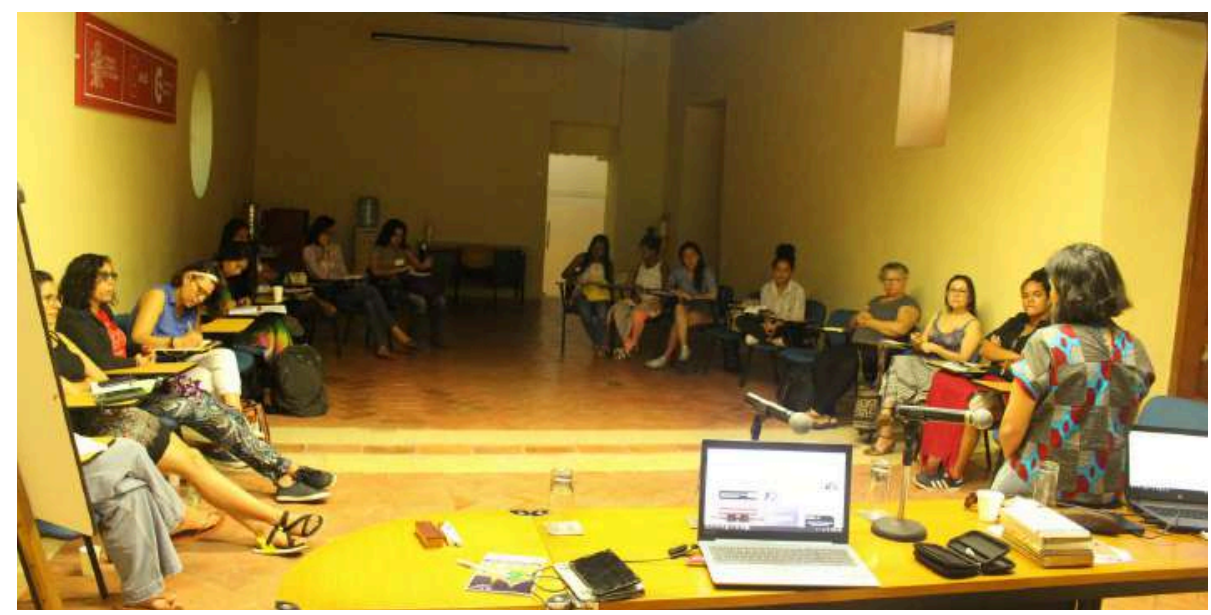

Figura 15. Taller de creación audiovisual Filma Mujer en la sede de la AECID, 2018. Fuente: archivo fotográfico del evento. Autor: fotógrafo de evento Filma Mujer.

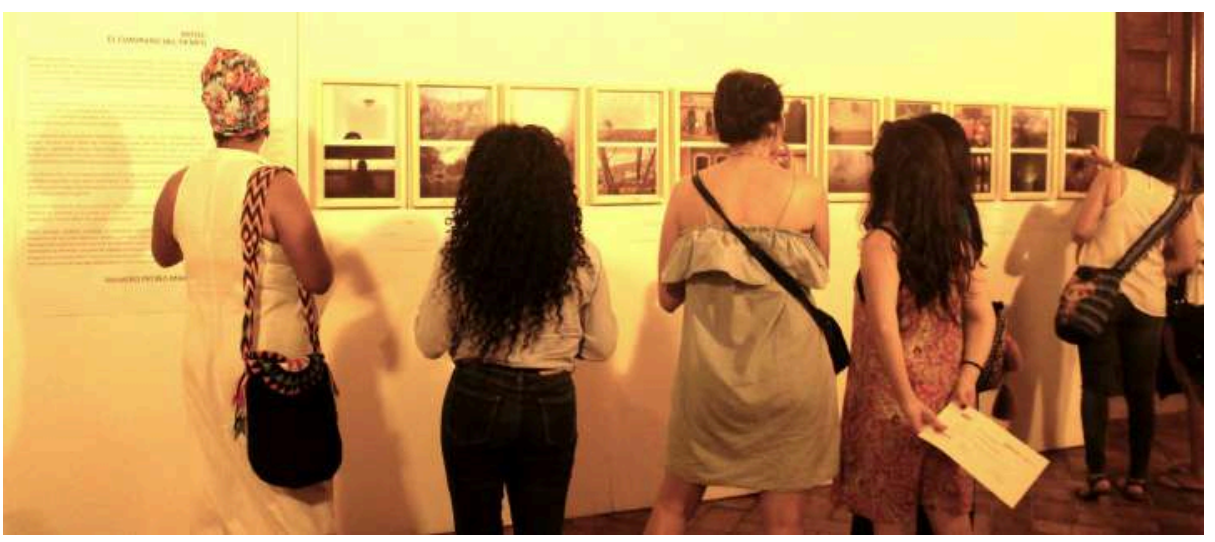

Figura 16. Exposición de Mitos en la sede de la AECID, 2018. Fuente: archivo fotográfico del evento Autor: fotógrafo de evento Filma Mujer. 


\section{Conclusiones}

En este artículo he expuesto, fundamentalmente, un ejercicio metodológico de investigación que desemboca en un proyecto de creación: Mitos en cuadrado del tiempo. Se trata de un caso específico de estudio a partir de la revisión de los enfoques autoetnográficos y narrativos en el marco de la investigación cualitativa. En el proceso confiero voz a las fotografías utilizando la variante personal del photovoice que presento, las (re)creo y (re)interpreto. Asumiéndome a mí misma como el objeto que estudio, se trata de poner en práctica y a prueba la metodología que me encuentro explorando para el proyecto de investigación doctoral en el que ya he empezado a implementar el enfoque autoetnográfico que espero presentar en futuras publicaciones. Este ejercicio se convierte en un aporte inicial ante la escasez de proyectos y publicaciones existentes en la academia latinoamericana y colombiana.

La fotografía, la autobiografía y la autoetnografía han sido fundamentales en el proceso de comprensión de mi sentimiento de pérdida y dolor con respecto a mi proceso de divorcio que fracturó tanto mi vida personal como mi proceso de investigación. Y sé que ese dolor y ese proceso largo y pedregoso nos sucede a todos, el de la pérdida (de algo, de alguien), seguramente lo hemos vivido en el espacio privado de la familia, la casa, una consulta psicológica, o en las confidencia que hacemos a los amigos más íntimos, pero siento que hacerlo público, introducirlo en un proceso conversacional, como diría Fontcuberta, en el marco de mi investigación ha elevado mi nivel de compresión del objeto de estudio (narración, memoria, imagen) de mi investigación y mis sujetos de estudio. El problema que subyace es que estos estados emocionales están socialmente prohibidos, los individuos se repliegan, se cohíben, se llenan de miedo y no dejan salir todo el dolor que sienten. He realizado este ejercicio metodológico para exorcizar mi dolor, sí, pero también para avanzar, pese a la dificultad de hacerlo, en mi compromiso investigativo. La confluencia de 
mi trabajo fotográfico de los últimos diez años y el ejercicio autoetnográfico llegado a mí a través de mi proceso investigativo en torno a la autobiografía, al igual que a Nan Goldin, haciendo fotos, han salvado mi vida.

Una de las oportunidades que ofrece este ejercicio es la de explorar/ experimentar en el ámbito de la psicología, ya que normalmente los procesos de psicoanálisis y las terapias psicológicas están prescritas en espacios privados, íntimos, en los que existe existencia humana se repliega, sin posibilidad de expandirse. Como se ha visto en este texto, las narrativas autobiográficas permiten liberar el dolor, porque mantenerlo en secreto lo hace nocivo. La terapia psicológica también posee ese punto secreto, íntimo, cerrado, constreñido. En este contexto, la autoetnografía ofrece posibilidades a los sujetos de liberar su potencial creador. Así que este ejercicio me sugiere que podría adaptarse a terapias psicológicas en las que se considere posible transfigurar el dolor a través de la imagen y la narrativa.

\section{Referencias}

Barthes R. (1990). La cámara lúcida. Barcelona, España: Paidós Ibérica, S.A.

Blanco, M. (2017). Investigación Narrativa y Autoetnografía: Semejanzas y Diferencias. Investigación Cualitativa, 2(1), 66-80. http://dx.doi.org/ 10.23935/2016/01037

Blanco, M. (2012). ¿Autobiografía o autoetnografía? Desacatos, (38), 169-178.

DOI: https://doi.org/10.29340/38.278

Camarero, J. (2011). Autobiografía: escritura y existencia. Barcelona, España: Anthropos Editorial.

Cartier-Bresson, H. (2014). Ver es un todo. Entrevistas y conversaciones 1951-1998. Barcelona, España: Gustavo Gili. 
Chase, S. (2005). Narrative inquiry: Still a field in the making. En N. Denzin y Y. Lincoln (Eds.) Handbook of qualitative research. Thousand Oaks, CA: Sage.

Colorado, O. (17 de febrero de 2013). Fotografía intimista: el documento personal [Mensaje en un blog]. Recuperado de https://oscarenfotos. com/2013/02/17/fotografia-intimista-el-documento-personal/

Douglas, K. \& Carless, D. (2013). A History of Autoethnographic Inquiry. En Holman Jones, S., Adams, T., Ellis, C. (Eds.), Handbook of Autoethnography (pp. 84-106). Recuperado de https://www.routledgehandbooks.com/ doi/10.4324/9781315427812.ch2

Dubé, G. (2017). La Auto-etnografía, un Método de Investigación Inclusivo. Visión Docente Con-Ciencia, 15 (83).

Fontcuberta, J. (2016). La furia de las imágenes. Barcelona, España: Galaxia Gutenberg.

Guerrero Muñoz, J. (2014). El valor de la auto-etnografía como fuente para la investigación social: del método a la narrativa. Azarbe, (3), 237-242. Recuperado de http://revistas.um.es/azarbe/article/view/198691/161851

Holman, S., Adams, T. \& Ellis, C. (2015). Handbook of autoethnography. Walnut Creek, CA: Left Coast Press.

Latz, A. (2017). Photovoice research in education and beyond: A practical guide from theory to exhibition. Nueva York, NY: Routledge.

Leal Acosta, M. y Ruiz Soto, M. (2010). El relato autobiográfico como apertura a la reinterpretación. En Acosta, C. y Alzate, C. (Eds.), Relatos Autobiográficos y otras formas del yo (pp. 85-95). Bogotá, Colombia: Siglo del Hombre Editores. 
Losilla, C. (2008). Al borde del abismo, desde la distancia. Notas sobre la enfermedad, el dolor y la muerte en la (auto)biografía filmada. En Martín Gutiérrez, G. (Eds.), Cineastas frente al espejo (pp. 121-135). Madrid, España: T\&B Editores.

Malinowski, B. (1982). Magia, ciencia, religión. Barcelona, España: Ariel.

Perret, J. (2015). Dévisager les apparences. La coleur des jours, pp. 38-39. No.16.

Perret, J. (2016). Et souviens-toi que je t'attends. La coleur des jours, p. 30-31. No.19

Perret, J. (2017). Pour un ange. La coleur des jours, pp. 38-39. No.22.

Russotto, M. (2010) Vidas malditas, vidas ingenuas, vidas artísticas. En Acosta, C. y Alzate, C. (Eds.), Relatos Autobiográficos y otras formas del yo (pp. 249-267). Bogotá, Colombia: Siglo del Hombre Editores.

Sontag, S. (1981). Sobre la fotografía. Barcelona, España: Edhasa.

Como citar: Viveros, C. E. (2020). Fotografía, autobiografía y autoetnografía en Mitos: el cuadrado del tiempo. Revista KEPES, 17(22), 465-500. https://doi.org/10.17151/kepes.2020.17.22.17 